\title{
CHARACTERISTICS OF DAMAGES IN NORWAY SPRUCE STANDS
}

\author{
Guntars Šṇepsts $^{1}$, Zane Bigača ${ }^{1,2}$, Iveta Desaine ${ }^{3}$, Jurğis Jansonss ${ }^{1}$, Jānis Donis ${ }^{1}$, Kārlis Strēlnieks ${ }^{4}$, Andis \\ Adamovičs ${ }^{1}$, Oskars Krišāns ${ }^{1}$ \\ ${ }^{1}$ Latvian State Forest Research Institute 'Silava', Latvia \\ ${ }^{2}$ Latvia University of Life Sciences and Technologies, Latvia \\ ${ }^{3}$ Skogssallskapet, Latvia \\ ${ }^{4}$ MVR LUX, Latvia \\ guntars.snepsts@silava.lv
}

\begin{abstract}
Norway spruce (Picea abies (L.) Karst.) is economically important tree species, vulnerable to impact of different biotoc (cervids, bark beetle etc.) and abiotic (wind, wet snow etc.) factors and their combinations, expected to increase in frequency and/or magnitude in future due to climate changes. The aim of the study was to characterize occurrence damages in Norway spruce stands in Latvia. Data from 635 National forest inventory sample plots were used in the analysis, thus providing the information primarily on the non-lethal damages, since the dead trees in most of the cases would be removed from the stands in sanitary cuts. Damages were reported for $11.6 \pm 1.1 \%$ of spruces from total basal area of spruces in the assessed pure and mixed stands. Admixture of other tree species or soil (group of forest types) had no significant effect on the proportion of damaged spruces. Also, no statistically significant differences in dimensions were observed between damaged and undamaged trees. The major cause of damages was browsing (three quarter of damaged spruces, in contrast to only one-quarter of the rest of the trees) and the highest proportion of damaged spruces were in stands in the age group $41-80$ years, significantly differing from that in younger (up to 20 years) stands, demonstrating both the preferences of cervids to a certain dimensions of spruce as well as accumulation of damages over time.
\end{abstract}

Key words: browsing damages, wind damages, admixture, mixed stands.

\section{Introduction}

Increase of the increment of Norway spruce (Picea abies (L.) Karst.) has been found in different countries, explained both by climate change (Pretzsch et al., 2014) as well as improved silvicultural practice. For example, Jansons et al. (2016a) found a rather long-lasting positive influence of initial fertilization to growth (radial increment) of Norway spruce. Nevertheless, following changes in climate might have unclear influence on trees both due to primary factors - limits of phenotypic plasticity to adapt in so rapidly changing climatic conditions (Schmidt-Vogt 1977) - as well as secondary factors, for example, improved conditions for spruce bark beetle, thus higher pressure to Norway spruce stands. Currently the major factors - climatic factors affecting the growth of trees had been analyzed and compared between tree species both in Latvia (Jansons et al., 2016b) and elsewhere. However, the influence of specific climatic factors may shift over time (Jansons et al., 2015b) due to climatic changes and such shifts are unpredictable without the specific studies. Also, the damages currently observed very seldom may appear in future climatic conditions e.g. drought crack (Zeltins et al., 2016). Such damages might be linked to the growth of trees, however, their impact at least to some extent might be modified by selection of the right (most appropriate) genotypes. Finding productive and robust provenances for a particular area is in the aims of genetic adaptation of forestry to climatic changes (Keskitalo et al., 2016; Rieksts-Riekstins et al., 2014). Tree breeding has been long practiced for different species (Jansons,
Gailis, Donis, 2011), including Norway spruce, and the potential impact of climatic changes is considered in current tree breeding programs to an extent possible to still retain the activity financially viable (Jansons et al., 2015a). Assessment of genotype $\mathrm{x}$ environment interaction (its scale, impact) is a key element in this approach (Jansons, 2008). Even so the Norway spruce regenerates surprisingly well also naturally not only in gaps, but also in larger-scale openings created e.g. by storm (Baders et al., 2017a) or clear cutting, and is capable of dominating the areas to a large extent after a longer period of time (c.a. 40 years), still it is mainly planted. Frequent planting with Norway spruce, predominately by the plants grown from seed orchard seeds, suggests a possibility to enhance adaptability via tree improvement, and thus limit the potential risks for investments (Haapanen et al., 2015; Dzerina et al., 2016). Overall, the genetic gain of around $10 \%$ for volume increment by selecting a seed source can be achieved (Jansson et al., 2013) increasing the above-ground biomass (Lībiete-Zālīte \& Jansons, 2011; Lỉbiete et al., 2017). Considering the above-mentioned, adding a transferred seed lots can be a tool to enhance adaptability (Lindner et al., 2008).

Major factors causing damages in forests across Europe are fires, wind storms and bark beetles. Their impact is expected to increase in future (Seidl et al., 2014). It may affect the tree species composition as well as cause notable economic losses. Norway spruce is vulnerable to all of these factors. Occurrence and severity of forest fires are affected by movements of 
large air masses (Kitenberga et al., 2018) influenced by climatic changes. The major impact of drought conditions during summer on the occurrence of fires has been detected, but also other climatic variables have some influence. The actual cause of the fires currently can be linked to human activity, in the same way as the size of the fires (Donis et al., 2017). Wind-storms have become increasingly more common during recent decades, causing significant damages for forestry as well as other sectors. Norway spruce has a shallow root system and therefore is not very wind-resistant, thus the ways to increase stability of the stands (for example, via different spacing, minimization of other damages e.g. root rot, different thinning regime) have been suggested. Bark beetle is often a secondary factor, affecting the spruces that have not been broken or uprooted by wind, but only damaged to some extent (weakened). Also, the conditions of this dendrophagous insect have been improving e.g. the years, when it can form more than one generation per year have become increasingly more common (Šmits, personal communication). During the peak of its population density, it may affect also rather healthy spruce stands. Additionally, browsing damages may be an important factor affecting spruces. State forest service data suggests that population densities of cervids have almost doubled from the mid $1990^{\text {th }}$ until now. Also, the monitoring of browsing damages demonstrates that the problem is significant. Browsing damage may cause a rot of the stem, deteriorating its economic value and potentially reducing the risk of wind damages. In order to understand the relative importance of the above-mentioned problem, the aim of the study was to characterize occurrence damages in Norway spruce stands in Latvia.

MSI sample plots stands characteristics

Table 1

\begin{tabular}{|l|l|c|c|c|c|c|c|c|c|}
\hline \multirow{3}{*}{ Soil } & \multirow{3}{*}{ Parameter } & \multicolumn{4}{|c|}{ Mixed stands } & \multicolumn{4}{c|}{ Pure stands } \\
\cline { 3 - 10 } & & A, years & $\mathrm{D}, \mathrm{cm}$ & $\mathrm{H}, \mathrm{m}$ & $\mathrm{G}, \mathrm{m}^{2} \mathrm{ha}^{-1}$ & A, years & $\mathrm{D}, \mathrm{cm}$ & $\mathrm{H}, \mathrm{m}$ & $\mathrm{G}, \mathrm{m}^{2} \mathrm{ha}^{-1}$ \\
\hline \multirow{3}{*}{ Dry } & Mean & 62.3 & 25.4 & 22.0 & 27.9 & 47.3 & 20.6 & 18.1 & 23.2 \\
Mineral & StdDev & 24.3 & 7.6 & 5.6 & 10.2 & 26.9 & 10.1 & 7.5 & 11.7 \\
Soil & Min & 13 & 4.2 & 3.8 & 4.0 & 10 & 2.2 & 2.7 & 0.4 \\
& Max & 117 & 45.0 & 31.6 & 52.4 & 163 & 64.8 & 36.3 & 58.0 \\
& Count & 125 & 125 & 125 & 125 & 169 & 169 & 169 & 169 \\
\hline \multirow{4}{*}{ Wet } & Mean & 67.5 & 24.6 & 20.7 & 26.9 & 42.0 & 16.9 & 15.2 & 20.8 \\
Mineral & StdDev & 29.9 & 7.0 & 4.8 & 9.2 & 22.9 & 7.1 & 5.9 & 11.5 \\
Soil & Min & 13 & 4.0 & 3.6 & 1.3 & 12 & 3.3 & 2.9 & 0.3 \\
& Max & 171 & 40.2 & 31.7 & 44.6 & 170 & 47.8 & 28.6 & 44.7 \\
& Count & 114 & 114 & 114 & 114 & 147 & 147 & 147 & 147 \\
\hline \multirow{3}{*}{ Peat Soil } & Mean & 66.0 & 23.5 & 20.7 & 28.0 & 44.3 & 18.5 & 15.9 & 21.6 \\
& StdDev & 23.8 & 6.1 & 4.6 & 7.6 & 25.9 & 8.8 & 6.3 & 10.4 \\
& Min & 19 & 7.4 & 9.1 & 11.1 & 20 & 4.5 & 4.7 & 2.1 \\
& Max & 126 & 35.3 & 27.8 & 40.9 & 158 & 37.0 & 27.3 & 40.7 \\
\hline
\end{tabular}

A - stand age, D - diameter at breast height, H - height, G - basel area.

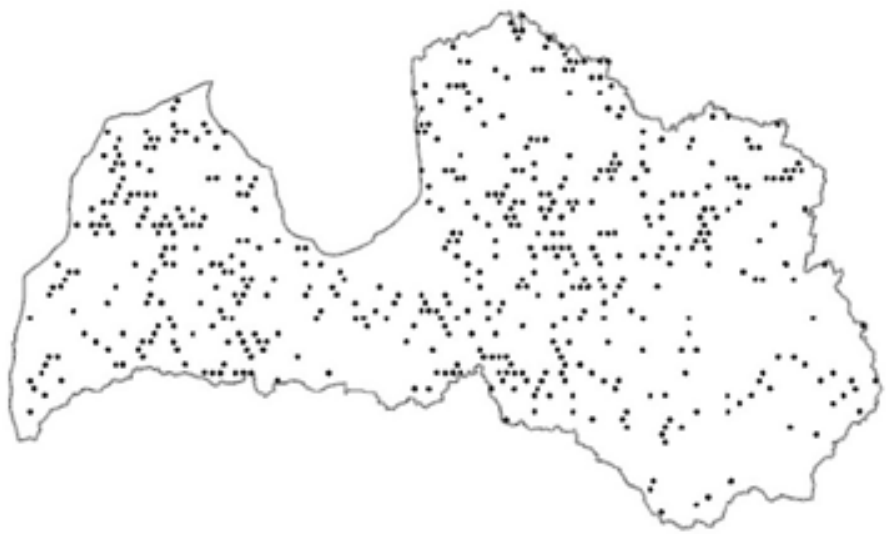

Figure 1. Distribution of sampling plots in the territory of Latvia. 


\section{Materials and Methods}

Data from 635 sample plots of National Forest Inventory (NFI) (obtained in the years 2004 - 2009) sampling network (evenly distributed across the territory of Latvia (Fig. 1)) with spruce as dominant species in the first layer were analysed. Sample plots were not divided into distinct sectors suggesting that each sample plot was located within one stand. Pure stands (PS) were defined as stands, where at least $75 \%$ of the first layer trees were spruce; remaining stands where classified as mixed (MS). In total, 360 and 275 PS and MS were distinguished, respectively. In all stands the proportion of species was calculated according to the volume. However, the total count of trees was used for stands where the height or mean quadratic DBH of trees with mean quadratic DBH was below $12 \mathrm{~m}$ and $10 \mathrm{~cm}$, respectively. According to soil types, PS were subdivided into another three distinct groups such as PS on dry mineral soils (DM), PS on waterlogged mineral soils (WM) and PS on peat soils (PT). The distribution of sample plots is representative (Table 1) allowing appropriate analysis of damages in spruce stands in Latvia.

Stands were divided into seven age groups with a step of 20 years $(1-20 ; 21-40 ; 41-60 ; 61-80$; 81$100 ; 101-120$; above 121) to analyse the effect of age on the proportion of damaged trees. According to methodology of the NFI, damages were distinguished in distinct groups in respect to cause - 1 (wind tipping, wind breakage, snow breakage, snow bend), 2 (water logging), 3 (animal damage), 4 (fire), 5 (diseases), 6 (pests) and 7 (other). According to methodology of the NFI, damages found for live trees only were evaluated. Therefore, the potential cause of decline of dead trees found in sample plots was not determined. Damages from groups 1,3 and 7 were analysed separately from the rest since the types of damages from other groups were notably less frequent in PS. However, to characterise the general resilience of forest stands, all types of damages were analysed together (Table 2). Data were prepared in MS Excel prior the analysis with SPSS for Windows with tools of linear mixed models.

\section{Results and Discussion}

Results show $10.4 \%$ damaged trees in total and $11.6 \%$ from all spruces. One third of all damaged trees had animal damages; however, this cause of damage for spruce was found for three quarters (Table 2).

In the stand level of PS, the mean proportion and mean basal area of damaged trees is $10.0 \pm 1.0 \%$ and $10.4 \pm 1.0 \%$, respectively. Nevertheless, for spruces these parameters reach $11.3 \pm 1.2 \%$ and $11.6 \pm 1.1 \%$, respectively. No statistically significant differences were found between the proportion of total count and basal area suggesting similar dimensions of both. Also, tree $\mathrm{DBH} /$ height ratio between damaged and undamaged trees did not differ significantly (Table 3). Considering that, only basal area was used in further analysis to characterize damages in PS.

Estimated marginal means of basal area in MS and PS is $9.0 \pm 1.3 \%$ and $9.4 \pm 1.4 \%$, respectively, from total basal area (Table 4). However, estimated marginal means of basal area of damaged spruces calculated from the total basal area of spruces is $10.4 \pm 1.5 \%$ and $10.4 \pm 1.5 \%$ in MS and PS, respectively. In DM the highest proportion of estimated marginal means of basal area of both all damaged trees $(10.9 \pm 1.0 \%)$ and damaged spruces (11.5 $\pm 1.2 \%)$ was observed. Lower values of this parameter were observed in WM (8.4 $\pm 1.2 \%$ and $8.9 \pm 1.4 \%$, respectively) and PT $(8.4 \pm 2.3 \%$ and $9.4 \pm 2.8 \%$, respectively).

The count of trees according to the type of damages

\begin{tabular}{|l|c|c|c|c|c|c|}
\hline \multirow{2}{*}{ Damages } & \multicolumn{3}{|c|}{ All species } & \multicolumn{3}{c|}{ Spruce } \\
\cline { 2 - 7 } & count & $\begin{array}{c}\text { proportion of } \\
\text { all, \% }\end{array}$ & $\begin{array}{c}\text { proportion of } \\
\text { damage, \% }\end{array}$ & count & $\begin{array}{c}\text { proportion of } \\
\text { all, \% }\end{array}$ & $\begin{array}{c}\text { proportion of } \\
\text { damage, \% }\end{array}$ \\
\hline Undamaged & 17164 & 89.6 & - & 13162 & 88.4 & - \\
Wind and Snow & 175 & 0.9 & 8.8 & 132 & 0.9 & 7.7 \\
Water logging & 2 & 0.0 & 0.1 & 2 & 0.0 & 0.1 \\
Animals & 1324 & 6.9 & 66.5 & 1288 & 8.7 & 74.8 \\
Fire & 3 & 0.0 & 0.2 & 0 & 0.0 & 0.0 \\
Diseases & 93 & 0.5 & 4.7 & 30 & 0.2 & 1.7 \\
Pests & 78 & 0.4 & 3.9 & 57 & 0.4 & 3.3 \\
Other & 316 & 1.6 & 15.9 & 213 & 1.4 & 12.4 \\
Damage Total & 1991 & 10.4 & 100.0 & 1722 & 11.6 & 100.0 \\
Grand Total & 19155 & 100.0 & - & 14884 & 100.0 & - \\
\hline
\end{tabular}


Differences in DBH and height between damaged and undamaged trees in PS

Table 3

\begin{tabular}{|c|c|c|c|c|c|c|c|}
\hline Species & Tree parameter & Damages & Mean & StdDev & $\begin{array}{c}\text { Confidence } \\
\alpha=0.05\end{array}$ & Count & $\begin{array}{c}\text { Countif } \\
>1.00\end{array}$ \\
\hline \multirow[t]{8}{*}{ All } & \multirow[t]{4}{*}{ Diameter } & All & 1.014 & 0.343 & 0.031 & 469 & 232 \\
\hline & & Wind and Snow & 0.909 & 0.418 & 0.080 & 104 & 38 \\
\hline & & Animals & 0.980 & 0.304 & 0.032 & 349 & 164 \\
\hline & & Forestry & 1.015 & 0.432 & 0.061 & 190 & 81 \\
\hline & \multirow[t]{4}{*}{ Height } & All & 0.996 & 0.229 & 0.021 & 469 & 245 \\
\hline & & Wind and Snow & 0.926 & 0.289 & 0.056 & 104 & 49 \\
\hline & & Animals & 0.973 & 0.214 & 0.022 & 349 & 172 \\
\hline & & Forestry & 1.010 & 0.302 & 0.043 & 190 & 97 \\
\hline \multirow[t]{8}{*}{ Spruce } & \multirow[t]{4}{*}{ Diameter } & All & 1.010 & 0.329 & 0.031 & 438 & 225 \\
\hline & & Wind and Snow & 1.001 & 0.474 & 0.102 & 83 & 38 \\
\hline & & Animals & 0.990 & 0.297 & 0.032 & 340 & 163 \\
\hline & & Forestry & 0.987 & 0.372 & 0.061 & 143 & 61 \\
\hline & \multirow[t]{4}{*}{ Height } & All & 1.005 & 0.247 & 0.023 & 438 & 238 \\
\hline & & Wind and Snow & 0.960 & 0.292 & 0.063 & 83 & 44 \\
\hline & & Animals & 0.978 & 0.210 & 0.022 & 340 & 170 \\
\hline & & Forestry & 0.974 & 0.295 & 0.048 & 143 & 72 \\
\hline
\end{tabular}

Estimated Marginal Means

Table 4

\begin{tabular}{|c|c|c|c|c|c|c|c|c|c|}
\hline \multirow[b]{2}{*}{ Species } & \multirow[b]{2}{*}{ Variable } & \multicolumn{2}{|c|}{ All damages } & \multicolumn{2}{|c|}{ Wind and Snow } & \multicolumn{2}{|c|}{ Animals } & \multicolumn{2}{|c|}{ Other } \\
\hline & & Mean & $\begin{array}{l}\text { Std. } \\
\text { Error }\end{array}$ & Mean & $\begin{array}{l}\text { Std. } \\
\text { Error }\end{array}$ & Mean & $\begin{array}{c}\text { Std. } \\
\text { Error }\end{array}$ & Mean & Std. Error \\
\hline \multirow{13}{*}{$\begin{array}{l}\text { All } \\
\text { species }\end{array}$} & Total & 0.092 & 0.010 & 0.008 & 0.003 & 0.008 & 0.000 & 0.020 & 0.004 \\
\hline & DryMinSoils & 0.109 & 0.010 & 0.007 & 0.004 & 0.059 & 0.008 & 0.020 & 0.004 \\
\hline & PeatSoils & 0.084 & 0.023 & 0.006 & 0.008 & 0.046 & 0.018 & 0.019 & 0.009 \\
\hline & WetMinSoils & 0.084 & 0.012 & 0.011 & 0.004 & 0.039 & 0.009 & 0.020 & 0.005 \\
\hline & Mixed & 0.090 & 0.013 & 0.010 & 0.004 & 0.041 & 0.010 & 0.018 & 0.005 \\
\hline & Pure & 0.094 & 0.014 & 0.006 & 0.005 & 0.054 & 0.011 & 0.021 & 0.005 \\
\hline & AgeGroup1 & 0.013 & 0.032 & 0.000 & 0.011 & 0.013 & 0.025 & 0.000 & 0.012 \\
\hline & AgeGroup2 & 0.074 & 0.011 & 0.008 & 0.004 & 0.047 & 0.009 & 0.011 & 0.004 \\
\hline & AgeGroup3 & 0.148 & 0.013 & 0.013 & 0.004 & 0.098 & 0.010 & 0.020 & 0.005 \\
\hline & AgeGroup4 & 0.131 & 0.013 & 0.005 & 0.004 & 0.084 & 0.010 & 0.026 & 0.005 \\
\hline & AgeGroup5 & 0.112 & 0.025 & 0.021 & 0.008 & 0.033 & 0.019 & 0.033 & 0.009 \\
\hline & AgeGroup6 & 0.091 & 0.033 & 0.009 & 0.011 & 0.036 & 0.026 & 0.010 & 0.012 \\
\hline & AgeGroup7 & 0.070 & 0.039 & 0.000 & 0.013 & 0.018 & 0.031 & 0.042 & 0.015 \\
\hline \multirow[t]{8}{*}{ Spruce } & Total & 0.099 & 0.011 & 0.009 & 0.004 & 0.060 & 0.009 & 0.019 & 0.004 \\
\hline & DryMinSoils & 0.115 & 0.012 & 0.009 & 0.004 & 0.068 & 0.010 & 0.020 & 0.005 \\
\hline & PeatSoils & 0.094 & 0.028 & 0.007 & 0.010 & 0.063 & 0.023 & 0.018 & 0.010 \\
\hline & WetMinSoils & 0.089 & 0.014 & 0.012 & 0.005 & 0.050 & 0.012 & 0.018 & 0.005 \\
\hline & Mixed & 0.104 & 0.015 & 0.014 & 0.005 & 0.059 & 0.013 & 0.018 & 0.006 \\
\hline & Pure & 0.094 & 0.017 & 0.005 & 0.006 & 0.061 & 0.014 & 0.019 & 0.006 \\
\hline & AgeGroup1 & 0.001 & 0.039 & 0.000 & 0.014 & 0.001 & 0.032 & 0.000 & 0.014 \\
\hline & AgeGroup2 & 0.081 & 0.013 & 0.010 & 0.005 & 0.060 & 0.011 & 0.010 & 0.005 \\
\hline \multirow[t]{5}{*}{ Spruce } & AgeGroup3 & 0.173 & 0.015 & 0.014 & 0.005 & 0.127 & 0.013 & 0.020 & 0.006 \\
\hline & AgeGroup4 & 0.148 & 0.016 & 0.006 & 0.006 & 0.112 & 0.013 & 0.023 & 0.006 \\
\hline & AgeGroup5 & 0.125 & 0.029 & 0.023 & 0.010 & 0.048 & 0.024 & 0.030 & 0.011 \\
\hline & AgeGroup6 & 0.084 & 0.039 & 0.010 & 0.014 & 0.047 & 0.032 & 0.007 & 0.014 \\
\hline & AgeGroup7 & 0.077 & 0.046 & 0.000 & 0.016 & 0.019 & 0.038 & 0.046 & 0.017 \\
\hline
\end{tabular}


Table 5

Type III Tests of Fixed Effects

\begin{tabular}{|c|c|c|c|c|c|c|c|c|c|}
\hline \multirow{2}{*}{ Damages } & \multirow[b]{2}{*}{ Source } & \multicolumn{4}{|c|}{ All species } & \multicolumn{4}{|c|}{ Spruce } \\
\hline & & $\begin{array}{l}\text { Nume- } \\
\text { rator df }\end{array}$ & $\begin{array}{c}\text { Denomi- } \\
\text { nator df }\end{array}$ & $\mathrm{F}$ & Sig. & $\begin{array}{l}\text { Nume- } \\
\text { rator df }\end{array}$ & $\begin{array}{l}\text { Denomi- } \\
\text { nator df }\end{array}$ & $\mathrm{F}$ & Sig. \\
\hline \multirow[t]{8}{*}{ All } & Intercept & 1 & 594 & 85.818 & 0.000 & 1 & 594 & 70.148 & 0.000 \\
\hline & Soil & 2 & 594 & 0.471 & 0.625 & 2 & 594 & 0.287 & 0.750 \\
\hline & Stand & 1 & 594 & 0.220 & 0.639 & 1 & 594 & 0.020 & 0.888 \\
\hline & Age & 6 & 594 & 5.368 & 0.000 & 6 & 594 & 5.961 & 0.000 \\
\hline & Soil*Stand & 2 & 594 & 0.321 & 0.725 & 2 & 594 & 1.490 & 0.226 \\
\hline & Soil*Age & 12 & 594 & 0.714 & 0.738 & 12 & 594 & 0.998 & 0.449 \\
\hline & Stand*Age & 6 & 594 & 1.243 & 0.283 & 6 & 594 & 0.616 & 0.718 \\
\hline & Soil*Stand*Age & 11 & 594 & 0.752 & 0.689 & 11 & 594 & 0.626 & 0.807 \\
\hline \multirow{8}{*}{$\begin{array}{l}\text { Wind and } \\
\text { Snow }\end{array}$} & Intercept & 1 & 594 & 6.052 & 0.014 & 1 & 594 & 5.071 & 0.025 \\
\hline & Soil & 2 & 594 & 0.238 & 0.788 & 2 & 594 & 0.199 & 0.820 \\
\hline & Stand & 1 & 594 & 0.394 & 0.531 & 1 & 594 & 0.971 & 0.325 \\
\hline & Age & 6 & 594 & 0.800 & 0.570 & 6 & 594 & 0.593 & 0.736 \\
\hline & Soil*Stand & 2 & 594 & 0.637 & 0.529 & 2 & 594 & 0.584 & 0.558 \\
\hline & Soil*Age & 12 & 594 & 0.741 & 0.711 & 12 & 594 & 0.660 & 0.790 \\
\hline & Stand*Age & 6 & 594 & 0.060 & 0.999 & 6 & 594 & 0.150 & 0.989 \\
\hline & Soil*Stand*Age & 11 & 594 & 0.661 & 0.776 & 11 & 594 & 0.685 & 0.753 \\
\hline \multirow[t]{8}{*}{ Animals } & Intercept & 1 & 594 & 37.052 & 0.000 & 1 & 594 & 37.779 & 0.000 \\
\hline & Soil & 2 & 594 & 0.603 & 0.547 & 2 & 594 & 0.288 & 0.750 \\
\hline & Stand & 1 & 594 & 1.116 & 0.291 & 1 & 594 & 0.134 & 0.714 \\
\hline & Age & 6 & 594 & 4.890 & 0.000 & 6 & 594 & 5.883 & 0.000 \\
\hline & Soil*Stand & 2 & 594 & 0.141 & 0.869 & 2 & 594 & 0.262 & 0.769 \\
\hline & Soil*Age & 12 & 594 & 0.811 & 0.639 & 12 & 594 & 1.056 & 0.396 \\
\hline & Stand*Age & 6 & 594 & 0.722 & 0.632 & 6 & 594 & 0.418 & 0.868 \\
\hline & Soil*Stand*Age & 11 & 594 & 0.648 & 0.787 & 11 & 594 & 0.708 & 0.732 \\
\hline \multirow[t]{8}{*}{ Forestry } & Intercept & 1 & 594 & 27.313 & 0.000 & 1 & 594 & 19.123 & 0.000 \\
\hline & Soil & 2 & 594 & 0.048 & 0.953 & 2 & 594 & 0.002 & 0.998 \\
\hline & Stand & 1 & 594 & 0.590 & 0.443 & 1 & 594 & 0.188 & 0.665 \\
\hline & Age & 6 & 594 & 1.984 & 0.066 & 6 & 594 & 1.397 & 0.213 \\
\hline & Soil*Stand & 2 & 594 & 0.140 & 0.870 & 2 & 594 & 0.380 & 0.684 \\
\hline & Soil*Age & 12 & 594 & 0.863 & 0.585 & 12 & 594 & 1.027 & 0.422 \\
\hline & Stand*Age & 6 & 594 & 1.003 & 0.422 & 6 & 594 & 0.628 & 0.708 \\
\hline & Soil*Stand*Age & 11 & 594 & 0.550 & 0.869 & 11 & 594 & 0.579 & 0.847 \\
\hline
\end{tabular}

The composition and soil type of stand did not have statistically significant influence on proportion of all damages of both all trees and spruces. Also, the frequency of distinct damage types was not affected significantly (Table 5). Significant effect on the proportion of both all damaged trees and animal damaged trees was observed for the stand age of I layer spruces. However, for both all trees and spruces no significant effect of the rest of groups of damages was observed (Table 5).

The proportion of both all trees and spruces in middle-aged ( $41-80$ years old) stands is significantly higher than in younger stands. More pronounced relations were observed for animal damages (Fig. 2)

Browsing damages to some extent might be linked to branch traits, affected also by genetics 

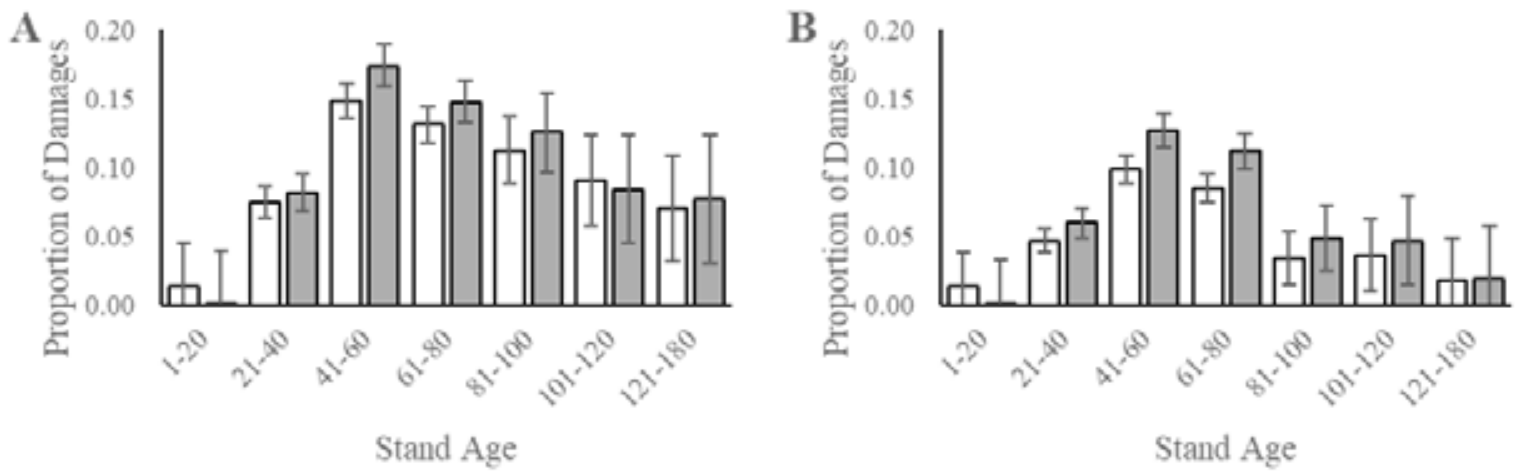

\section{口All species Q QSpruce}

Figure 1. The proportion of basal area of damaged trees in relation to the age group.

All damages (A), animal damages (B).

(Baders et al., 2017b; Jansons et al., 2006), but are primarily influenced by population densities of cervids. Moreover, they tend to accumulate over time, since the healing-over of a browsing scare takes a long time.

All age classes of all damaged trees and spruces, all damages and animal damages can be distinguished in two statistically significantly different groups-stands till age of 40 years and stands above 80 years.

\section{Conclusions}

1. The mean basal area of damaged trees is $10.4 \pm$ $1.0 \%$ from the total basal area of stand. However, the basal area of damaged spruces is $11.6 \pm 1.1 \%$ from the total basal area of spruces.

2. No statistically significant differences in dimensions between damaged and undamaged trees were observed. The proportion of damaged trees does not differ significantly between both PS and MS, and soil types.

3. Spruce is prone to browsing damages: one third of all damaged trees had animal damages; however, this cause of damage for spruce was found for three quarters. This is the major cause of damage that does not kill the tree; thus, its occurrence in the analyzed sample is not affected by the sanitary cuttings (salvage logging).

4. The highest proportion of damaged trees is in stands between the years $41-80$, which is statistically significantly higher compared that with up to 20- year old stands.

\section{Acknowledgements}

The study was supported by ERDF project "Development of decision support tool for prognosis of storm damages in forest stands on peat soils" (No. 1.1.1.1/16/A/260)

\section{References}

1. Baders, E., Senhofa, S., Purina, L., \& Jansons, A. (2017a). Natural succession of Norway spruce stands in hemiboreal forests: case study in Slitere national park, Latvia. Baltic Forestry. 23(2), 522-528.

2. Baders, E., Donis, J., Snepsts, G., Adamovics, A., \& Jansons, A. (2017b). Pruning effect on Norway spruce (Picea abies (L.) Karst.) growth and quality. Forestry Studies. 66, 33-48.

3. Donis, J., Kitenberga, M., Snepsts, G., Matisons, R., Zarins, J., \& Jansons, A. (2017). The forest fire regime in Latvia during 1922-2014. Silva Fennica. 51 (5). DOI: 10.14214/sf.7746.

4. Dzerina, B., Girdziusas, S., Lazdina, D., Lazdins, A., Jansons, J., Neimane, U., \& Jansons, Ā. (2016). Influence of spot mounding on height growth and tending of Norway spruce: case study in Latvia. Forestry Studies. 65, 24-33. DOI: 10.1515/fsmu-2016-0009.

5. Haapanen, M., Jansson, G., Nielsen, U.B., Steffenrem, A., \& Stener, L.G. (2015). The status of tree breeding and its potential for improving biomass production: A review of breeding activities and genetic gains in Scandinavia and Finland. Uppsala: Skogforsk.

6. Jansons, Ā. (2008). Genotype-environment interaction in Latvian Scots pine growth and quality traits and its impact on progeny testing. In: Z. Gaile (ed.) Proceeding of international scientific conference Research for Rural Development, 21-23 of May 2008 (pp. 128-136). Jelgava, Latvija: LLU.

7. Jansons, Ā., Baumanis, I., Dreimanis, A., \& Gailis, A. (2006). Variability and genetic determination of Scots pine quantitative traits at the age of 32 years. In: Z. Gaile (ed.) Proceeding of international scientific conference Research for Rural Development, 17-20 of May 2006 (pp. 289-295). Jelgava, Latvia: LLU. 
8. Jansons, A., Donis, J., Danusevičius, D., \& Baumanis, I. (2015a). Differential analysis for next breeding cycle for Norway spruce in Latvia. Baltic Forestry. 21(2), 285-297.

9. Jansons, Ā., Gailis, A., \& Donis, J. (2011). Profitability of silver birch (Betula pendula Roth.) breeding in Latvia. In: Z. Gaile (ed.) Proceedings of the $17^{\text {th }}$ international scientific conference Research for Rural Development, 18-20 May 2011 (pp. 33-38). Jelgava, Latvia: LLU.

10. Jansons, Ā., Matisons, R., Krišāns, O., Džeriņa, B., \& Zeps, M. (2016a). Effect of initial fertilization on 34-year increment and wood properties of Norway spruce in Latvia. Silva Fennica. 50 (1), 8 p.

11. Jansons, Ā., Matisons, R., Šēnhofa, S., Katrevičs, J., \& Jansons, J. (2016b). High-frequency variation of tree-ring width of some native and alien tree species in Latvia during the period 1965-2009. Dendrochronologia. 40, 151-158.

12. Jansons, Ā., Matisons, R., Zadina, M., Sisenis, L., \& Jansons, J. (2015b). The effect of climatic factors on height increment of Scots pine in sites differing by continentality in Latvia. Silva Fennica. 49 (3), 14p.

13. Jansson, G., Danusevičius, D., Grotehusman, H., Kowalczyk, J., Krajmerova, D., Skrøppa, T., \& Wolf, H. (2013). Norway spruce (Picea abies (L.) H. Karst.). Pâques L. (ed.) Forest Tree Breeding in Europe. Managing Forest Ecosystems, (vol 25, pp. 123-176). Springer, Dordrecht.

14. Keskitalo, E.C.H., Bergh, J., Felton, A., Björkman, C., Berlin, M., Axelsson, P., \& Boberg, J. (2016). Adaptation to climate change in Swedish forestry. Forests. 7(2), 28 p. DOI: 10.3390/f7020028.

15. Kitenberga, M., Matisons, R., Jansons, A., \& Donis, J. (2018). Teleconnection between the Atlantic sea surface temperature and forest fires in Latvia and Estonia. Silva Fennica. 52 (1), 8 p. DOI: 10.14214/ sf.7771.

16. Lībiete, Z., Matisons, R., Rieksts-Riekstins, J., Priedītis, A., Jansons, J., Smilga, J., Done, G., \& Jansons, $\bar{A}$. (2017). Aboveground biomass equations of 40 - year old Norway spruce in Latvia. Baltic Forestry. 23(2), 515-521.

17. Lībiete-Zālīte, Z., \& Jansons, Ā. (2011). Influence of genetic factors on Norway spruce (Picea abies (L.) Karst.) above-ground biomass and its distribution. In: Z. Gaile (ed.) Proceedings of the $17^{\text {th }}$ international scientific conference Research for Rural Development, 18-20 May 2011 (pp. 39-45). Jelgava, Latvia: LLU.

18. Lindner, M., Garcia-Gonzalo, J., Kolström, M., Green, T., Reguera, R., Maroschek, M., \& Kremer, A. (2008). Impacts of climate change on European forests and options for adaptation. Report to the European Commission Directorate-General for Agriculture and Rural Development. Rome: EK (173).

19. Pretzsch, H., Biber, P., Schütze, G., Uhl, E., \& Rötzer, T. (2014). Forest stand growth dynamics in Central Europe have accelerated since 1870. Nature Communications. 5. DOI: 10.1038/ncomms5967.

20. Rieksts-Riekstins, J., Jansons, A., Smilga, J., Baumanis, I., Ray, D., \& Connolly, T. (2014). Climate suitability effect on tree growth and survival for Scots pine provenances in Latvia. In: Z. Gaile (ed.) Proceedings of the $20^{\text {th }}$ international scientific conference Research for Rural Development, 21-23 May 2014 (pp. 57-62). Jelgava, Latvia: LLU.

21. Seidl, R., Schelhaas, M.-J., Rammer, W., \& Verkerk, P.J. (2014). Increasing forest disturbances in Europe and their impact on carbon storage. Nature Climate Change, 4, 806-810. Retrieved from DOI: 10.1038/ nclimate2318.

22. Schmidt Vogt, H. (1977). Die Fichte. Ein Handbuch in zwei Bänden. I Taxonomie, Verbreitung, Morphologie, Ökologie, Waldgesellschaften. (The spruce. A manual in two volumes. I Taxonomy, distribution, morphology, ecology, forest communities). XVIII + 647 S., 304 Abb., 60 Übersichten. Verlag Paul Parey, Hamburg, Berlin. ISBN 3490082168. (in German).

23. Zeltiňš, P., Katrevičs, J., Gailis, A., Maaten, T., Jansons, J., \& Jansons, Ā. (2016). Stem cracks of Norway spruce (Picea abies (L.) Karst.) provenances in Western Latvia. Forestry Studies. 65, 57-63. 